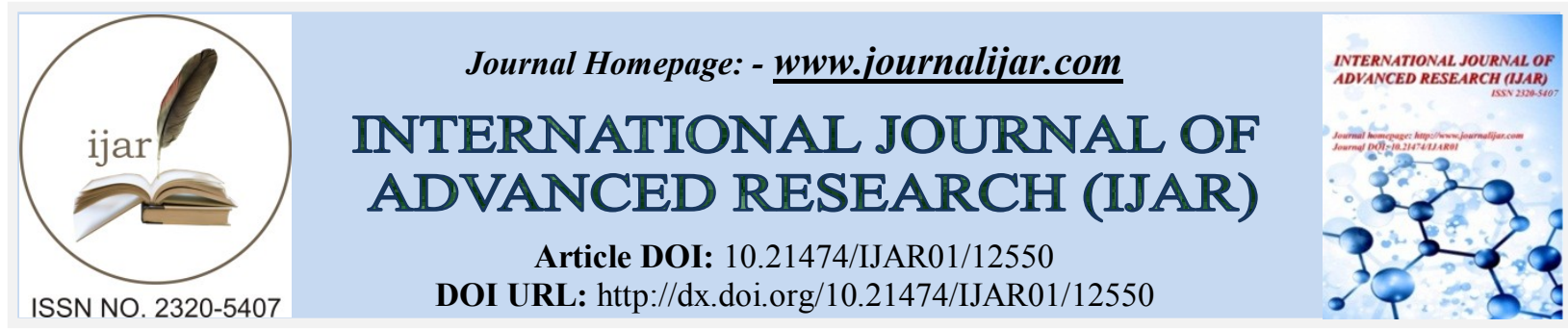

RESEARCH ARTICLE

\title{
SPATIO-TEMPORAL CHANGE IN SNOW COVER AREA USING RS \& GIS IN THE GORI GANGA WATERSHED, KUMAUN HIGHER HIMALAYA
}

\author{
D.S. Parihar and J.S. Rawat
}

Department of Geography, Kumaun University, S.S.J. Campus, Almora, Uttarakhand (India).

\section{Manuscript Info}

Manuscript History

Received: 05 January 2021

Final Accepted: 09 February 2021

Published: March 2021

Key words:

NDSI, Snow Cover Dynamics, Kumaun

Himalaya, Remote Sensing and GIS,

Gori Ganga Watershed

\begin{abstract}
Present research paper is an attempt to examine the dynamics of snow cover by using Normalized Difference Snow Index (NDSI) in Gori Ganga watershed, Kumaun Himalaya, Uttarakhand (India). For the study of snow cover of Landsat satellite imageries of three different time periods like Landsat TM of 1990, Landsat TM of 1999 and Landsat TM 2016 were used. Geographical distribution of snow cover reveals that in 1990 about $30.97 \%\left(678.87 \mathrm{~km}^{2}\right)$, in 1999 about $25.77 \%$ $\left(564.92 \mathrm{~km}^{2}\right)$ area of the Gori Ganga watershed was under snow cover while in 2016 the snow cover was found only $15.08 \%\left(330.44 \mathrm{~km}^{2}\right)$. These data suggest that due to global warming about $348.43 \mathrm{~km}^{2}$ snow cover of Gori Ganga watershed has been converted into non-snow cover area at an average rate $13.40 \mathrm{~km}^{2} /$ year during the last 26 years.
\end{abstract}

Copy Right, IJAR, 2021,. All rights reserved.

\section{Introduction:-}

Snow is a key component for energy balance of the earth's i.e. environment, climate and a major source of fresh water in many Himalayan regions. The Himalayan glaciers and region home of permanent snowfields, which from the largest bodies of ice outside of polar ice caps (Raina and Srivastava, 2008). As a important regional water resource, the Himalayan snow caps and winter seasonal snow melts make an major contribution to the drinking water, agriculture, and hydropower supply for a populated region in downstream river basins (Immerzeel et al. 2010). Satellite-based remote sensing is a convenient tool for the study of cryosphere that allows to carry out investigations over large inaccessible areas and analysis has been done using moderate-resolution imaging spectroradiometer (MODIS) satellite data for the past 11 years (2000-2010) with the temporal snow cover being derived using the Normalized Difference Snow Index (Joshi et al. 2015).

In the recent past, satellite-based remote sensing techniques have been widely used globally for investigating glacier fluctuations and snow cover changes (Kulkarni and Rathore, 2003). Due to accessibility and difficult terrain, only limited numbers of glaciers are monitored continuously in Indian Himalaya after 2000 to 2017. The Gangotri glacier, Dokriani glacier, Pindari glacier, Milam glacier, Chorbari glacier, Satopant glacier, Bhagirathi Kharak glacier, Parbati glacier, Samudra Tapu Glacier, Chhota Shigri glacier and Kolahoi Glacier are the most studied glaciers with field and satellite data (Naithani et al. 2001; Kulkarni et al. 2005; Dobhal et al. 2008, Dobhal et al. 2004; Raj 2011; Bhambri et al. 2012; Bali et al. 2013; Raj et al. 2014; Mehta et al. 2014; Rashid et al. 2017). Table 1 present a compilation of recession of some selected glaciers in the Indian Himalaya.

The fundamental objective of the present paper is to study the snow cover dynamic of a Higher Himalayan watershed viz. the Gori Ganga. 
Table 1:- Recession of Himalayan glaciers through last century.

\begin{tabular}{|l|c|c|c|c|l|}
\hline \multicolumn{1}{|c|}{ Glacier } & Period & Years & Recession $(\mathrm{M})$ & Average Rate (M/Yr) & \multicolumn{1}{c|}{ References } \\
\hline Pindari Glacier & $1966-2010$ & 44 & 379 & 8.6 & Bali et al. 2013 \\
\hline Parbat Glacier & $1962-2001$ & 39 & 6569 & 168 & Kulkarni et al. 2005 \\
\hline Chorabari Glacier & $1962-2012$ & 50 & 344 & 6.8 & Mehta et al. 2014 \\
\hline Gangotri Glacier & $1962-1999$ & 37 & 1250 & 34 & Naithani et al. 2001 \\
& $1965-2006$ & 41 & 819 & 19 & Bhambri et al. 2012 \\
\hline Milam Glacier & $1954-2006$ & 52 & 1328 & 25.5 & Raj 2011 \\
\hline Dokriani Glacier & $1962-2000$ & 38 & 641.5 & 16.88 & Dobhal et al. 2008 \\
\hline Kolhoi Glacier & $1857-2014$ & 157 & 2850 & 18.2 & Rashid et al. 2017 \\
\hline Tiprabank Glacier & $1960-1986$ & 26 & 325 & 12.5 & Dobhal et al. 2004 \\
\hline South Lhonak & $1962-2008$ & 46 & 1900 & 41 & Raj et al. 2014 \\
\hline
\end{tabular}

\section{Study Area}

The study area, viz., the Gori Ganga Watershed (Kumaun Himalaya) extends between $29^{\circ} 45^{\prime} 0^{\prime}$ ' $\mathrm{N}$ to $30^{\circ} 35^{\prime} 47^{\prime}$ ' $\mathrm{N}$ latitudes and $79^{\circ} 59^{\prime} 33^{\prime \prime} \mathrm{E}$ to $80^{\circ} 29^{\prime} 25^{\prime \prime} \mathrm{E}$ longitude, and encompasses an area of $2191.93 \mathrm{~km}^{2}$ (Figure 1). The altitude of the Gori Ganga watershed varies in between $626 \mathrm{~m}$ and $6639 \mathrm{~m}$. The Gori Ganga watershed has 168 villages and total population is about 40616 (2011). Gori Ganga watershed spreads in three blocks, i.e., Munsyari, Dharchula and Didihat, in three Tehsils, i.e., Munsyari, Dharchula and Didihat. Munsyari remains one of the last accessible hill stations by motor road in the region. The Munsyari and Madkote towns located in the study area are currently the starting point for many track routes into the Himalayan interior.

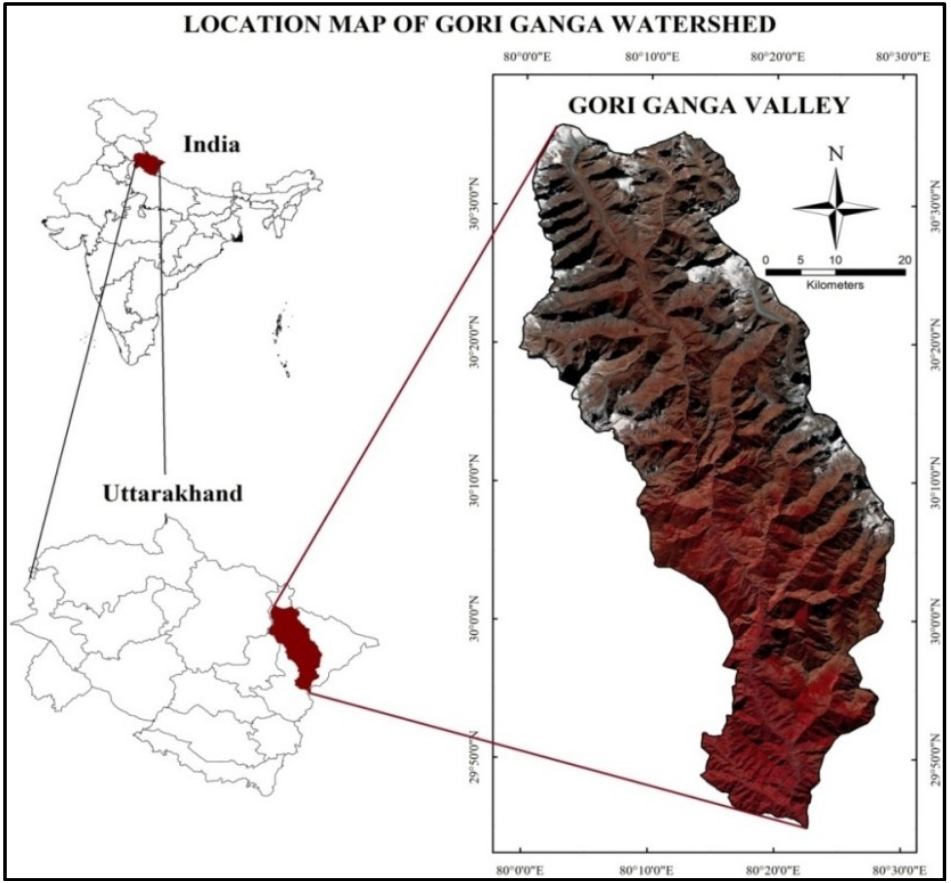

Figure 1:- Location map of the study area Viz., Gori Ganga watershed, Kumaun Higher Himalaya.

\section{Methodology:-}

To examine the snow cover area in the Gori Ganga watershed, Landsat satellite imageries of three different dates and years were acquired by Global Land Cover Facility (GLCF) and United States Geological Survey (USGS) Earth explorer. The first imagery used in the present study is Landsat TM of 18 November 1990 at $30 \mathrm{~m}$ resolution. The second image is of Landsat TM of 15 November 1999 at $30 \mathrm{~m}$ resolution and the third image used for the present study is Landsat TM of 28 November 2016 at $30 \mathrm{~m}$ resolution. These imageries helped in understanding extend of snow cover area in the watershed over the last 26 years (i.e. 1990 to 2016). Figure 2 is presenting a flowchart of the methodology adopted. Additionally, the reflectance of clouds remains high in the SWIR band, thus NDSI allows discriminating some clouds and snow. NDSI is useful for the identification of snow and ice and for discriminating 
snow/ice from most cumulus clouds. This method is generally used for snow cover mapping using satellite data (Kulkarni et al. 2006; Gupta et al. 2005; Negi et al. 2008). NDSI is defined by the following relation and it ranges from -1 to +1 (Kulkarni et al., 2003). To handle the mixed area, the threshold value of NDSI was lowered from 0.4 to 0.1 (Klein et al. 1998).

\section{Result And Discussion:-}

The results obtained through the analysis of NDSI imagery are diagrammatically illustrated in Figure 3 and 4 and are registered in Table 2 and 3. Figure 3 depicts distribution of NDSI variation while Figure 4 depicts geographical distribution of snow cover area in 1990, 1999 and 2016 in the study area. Figure 5 depicts dynamics of snow cover area in 1990 to 2016. A brief account of these results it's discussed in the following paragraphs.

\section{Normalized Difference Snow Index (NDSI)}

NDSI is useful for the identification of snow and ice and for discriminating snow/ice from most cumulus clouds. This method is generally used for snow cover mapping using satellite data (Kulkarni et al. 2006; Gupta et al. 2005; Negi et al. 2008). NDSI uses the high and low reflection of snow in visible (green) and shortwave infrared (SWIR) regions respectively and it can also delineate and map the snow in mountain shadows. Additionally, the reflectance of clouds remains high in the SWIR band. Thus NDSI allows discriminating clouds and snow. NDSI is defined by the following relation and it ranges from -1 to +1 (Kulkarni et al., 2002).

$$
\text { NDVI }=\frac{\text { Green }- \text { SWIR }}{\text { Green }+ \text { SWIR }}
$$

In the methodology described for NDSI using Landsat data. Using ArcGIS software, three different years (1990, 1999, and 2016) Landsat data were taken for calculating the NDSI index for Gori Ganga watershed. A threshold value for NDSI of 0.4 is defined for the imageries of different sensors (Xiao et al. 2001). To handle the mixed area, the threshold value of NDSI was lowered from 0.4 to 0.1 (Klein et al. 1998). Figure 3 is the normalized difference snow index which is based on Landsat- 8 satellite imageries of three different time periods, i.e., Landsat TM of 1990 , 1999 and 2016.

\section{Status of Snow Cover}

From the Figure 4 which is based on NDSI values of Figure 3, area under snow cover for different years was worked out which is presented in Table 2. Table 2 reveals that the snow cover area in Gori Ganga watershed was about $30.97 \%\left(678.87 \mathrm{~km}^{2}\right)$ in $1990,25.77 \%\left(564.92 \mathrm{~km}^{2}\right)$ in 1999 and $15.08 \%\left(330.44 \mathrm{~km}^{2}\right)$ in 2016.

Table 2:- Snow cover area and their percentage in different years in the Gori Ganga watershed (based on Landsat-8 Satellite imageries).

\begin{tabular}{|c|c|c|c|}
\hline Years & Area in $\mathrm{km}^{2}$ & Percentage & Total Area $\mathrm{km}^{2}$ \\
\hline 1990 & 678.87 & 30.97 & 2191.93 \\
\hline 1999 & 564.92 & 25.77 & 2191.93 \\
\hline 2016 & 330.44 & 15.08 & 2191.93 \\
\hline
\end{tabular}

\section{Shifting in Snow Cover}

The data presented in Table 3 suggest that due to global warming the snow cover area in the Gori Ganga watershed has been shifted towards higher elevation and has been depleted considerably during the last two and half decades. Result reveal that during 1990 to 2016 , about $348.43 \mathrm{~km}^{2}$ snow cover of the Gori Ganga watershed has been converted into non-snow cover area from the snow cover area at an average rate of $13.40 \mathrm{~km}^{2} /$ year (Table 3 ). The change from snow cover area to non-snow cover area during 1990 to 1999 was found about $104.64 \mathrm{~km}^{2}$ at the rate of $11.63 \mathrm{~km}^{2} /$ year and 1999 to 2016 was found about $243.79 \mathrm{~km}^{2}$ at the rate of $14.34 \mathrm{~km}^{2} /$ year, respectively (Table 3 ).

Table 3:- Amount and rate of snow cover change during different period in the Gori Ganga watershed, Kumaun Himalaya, Uttarakhand (India).

\begin{tabular}{|c|c|c|c|}
\hline \multirow{2}{*}{ Year } & \multirow{2}{*}{ Period } & \multicolumn{2}{|c|}{ Shifting of Snow Cover } \\
\cline { 2 - 3 } & & Area & Shifting Rate \\
\hline $1990-1999$ & 9 & $104.64 \mathrm{~km}^{2}$ & $11.63 \mathrm{~km}^{2} /$ year \\
\hline $1999-2016$ & 17 & $243.79 \mathrm{~km}^{2}$ & $14.34 \mathrm{~km}^{2} /$ year \\
\hline $1990-2016$ & 26 & $348.43 \mathrm{~km}^{2}$ & $\mathrm{~km} /$ year 1.40 \\
\hline
\end{tabular}




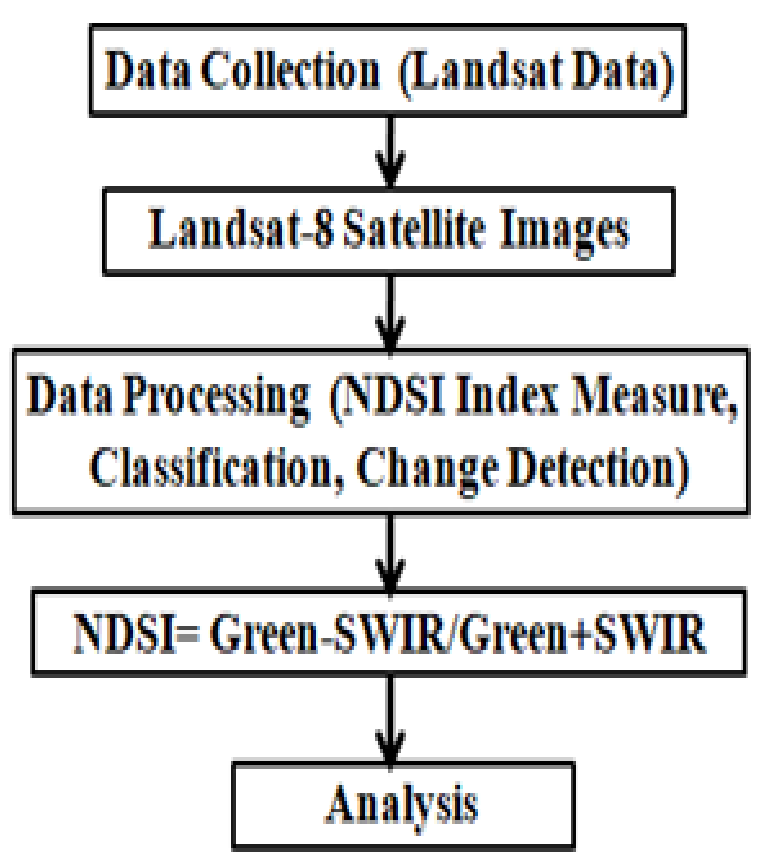

Figure 2: Flowchart of methodology

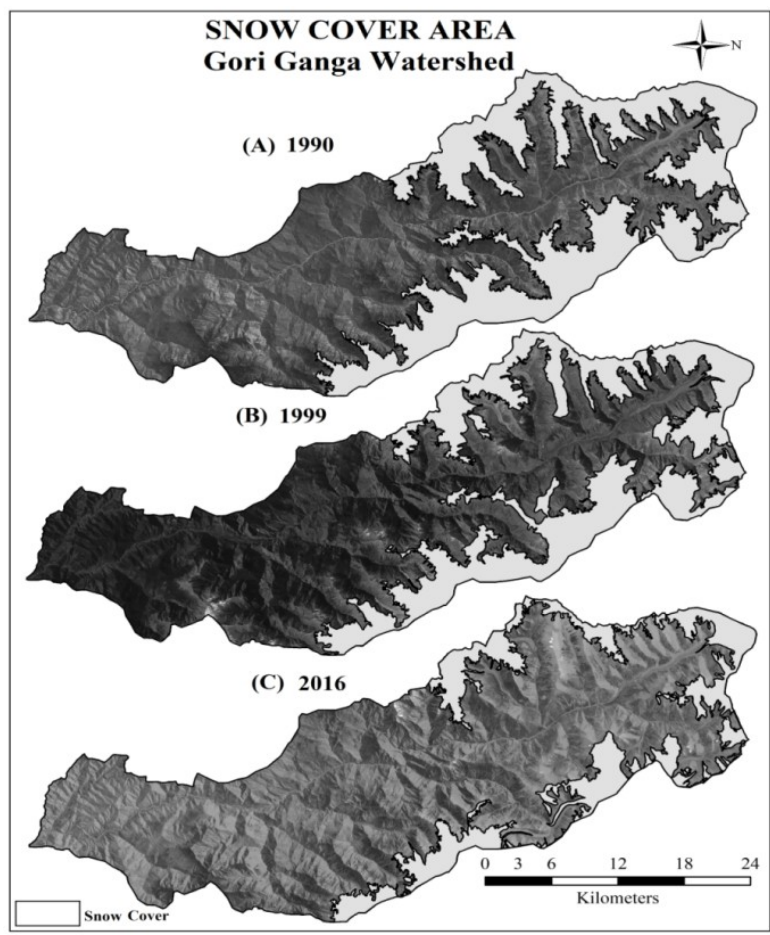

Figure 4: Geographical distribution of snow cover area based on NDSI Values $(>0.4)$ in different years in the gori ganga watershed, (A) 1990, (B) 1999 and (C) 2016 (based on Landsat-8, Satellite imageries).

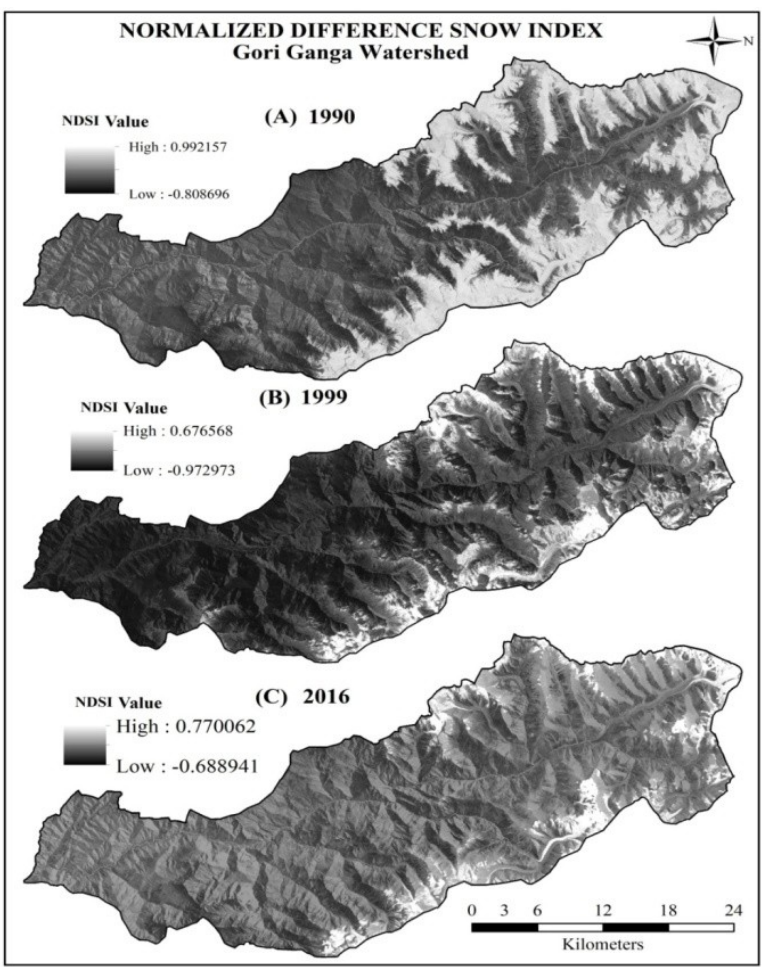

Figure 3: Normalized Difference Snow Index (NDSI) map values $(>0.4)$ in different years in the Gori Ganga watershed, (A) 1990, (B) 1999 and (C) 2016 (based on Landsat-8 Satellite imageries).

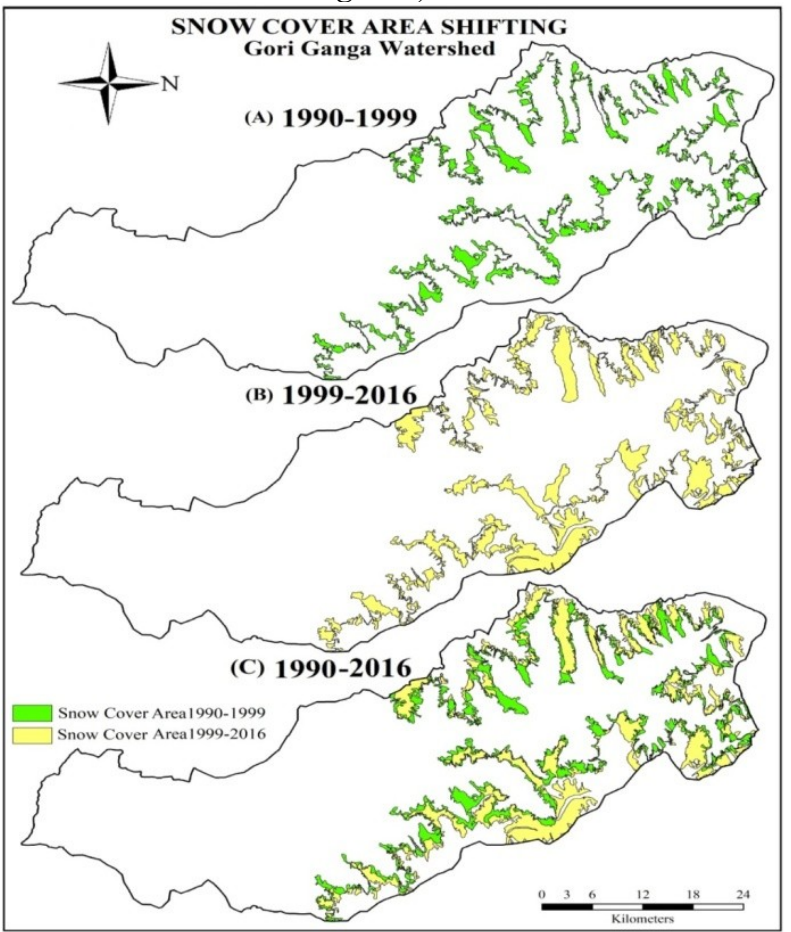

Figure 5: Dynamic distribution of snow cover area based on NDSI values $(>0.4)$ in different years in the Gori Ganga watershed, (A) 1990, (B) 1999 and (C) 2016 (based on Landsat-8, Satellite imageries). 


\section{Conclusion:-}

The present study was carried out in a Kumaun Himalayan watershed, viz., Gori Ganga watershed. The study reveals that from 1990 to 2016 about $348.43 \mathrm{~km}^{2}$ area of the watershed has been converted into non-snow cover area from snow cover area. With the help of these data, it can be extrapolated that the snow cover area in Gori Ganga watershed is depleting at the average rate of $13.40 \mathrm{~km}^{2}$ per year. It is evident from present study that the snow cover area is decline confirmed steadily in the Kumaun Himalaya due to global warming. If the trends of snow cover depletion, the water resource of the region will be in danger which may result in severe environmental degradation, social disruption and ecological damages in the Kumaun Himalayan region. This study has well demonstrated the applications of geospatial technology in studying snow dynemics.

\section{References:-}

1. Bali, R., Ali, S.N., Agarwal, K.K., Rastogi, S.K., Krishna, K., Srivastava, P. (2013): Chronology of late quaternary glaciations in the Pinder valley, Alaknanda basin, central Himalaya (India). Journal of Asian Earth Science, Vol. 66, pp. 224-233.

2. Bhambri, R., Bolch, T., Chaujar, R.K. (2012): Frontal recession of Gangotri Glacier, Garhwal Himalayas from 1965 to 2006, measure through high-resolution remote sensing data. Current Science, Vol. 102 (3), pp. 489-494.

3. Dobhal, D.P., Gergan, J.T., Thayyen, Renoj J. (2004): Recession and Morphogeometrical changes of Dokriani glacier (1962-1995) Garhwal Himalaya, India. Current Science, Vol. 86 (5), pp. 692-696.

4. Dobhal, D.P., Gergan, J.T., Thayyen, Renoj J. (2008): Mass balance studies of Dokriani glacier from 1992 to 2000, Garhwal Himalaya, India. Bulletin of Glaciological Research, Vol. 25, pp. 9-17.

5. Gupta, R.P., Haritashya, U.K., Singh, P. (2005): Mapping dry/wet snow cover in the Indian Himalayas using IRS multispectral imagery. Remote Sensing Environment, Vol. 97, pp 458-469.

6. Immerzeel, W.W., Van Breek L.P.H., Bierkens M.F.P. (2010): Climate change will affect the Asian Water Towers. Science Vol. 328, pp. 1382-1385.

7. Klein, A.G., Hall, D.K., and Riggs, G.A. (1998): Improving snow cover mapping in forests through the use of a canopy reflectance model, Hydrol. Proc, Vol. 12, pp. 1723-1744.

8. Kulkarni, A.V. and Rathore, B.P. (2003): Snow cover monitoring in Baspa Basin using IRS WIFS data. Mausam, Vol. 54 (1), pp. 335-340.

9. Kulkarni, A.V. and Rathore, B. P. (2005): Alarming retreat of Parbati glacier, Beas basin, Himalchal Pradesh. Current Science, Vol. 88, pp. 1844-1850.

10. Kulkarni, A.V., Dhar, S., Rathor B.P., Raj K.B.G., Kalia, R. (2006): Recession of Samundratapu Glacier, Chandra river basin, Himanchal Pradesh. Journal of Indian Society Remote Sensing, Vol. 34 (1), pp. 39-46.

11. Mehta, Manish., Dobhal, D.P., Kesarwani, K., Pratap, B., Kumar, A., Verma, A. (2014): Monitoring of glacier changes and response time in Chorabari Glacier, central Himalaya, Garhwal, India. Current Science, Vol. 107 (2), pp. 281-289.

12. Naithani, A.K., Nainwal, H.C., Sati, K.K., Prasad, C. (2001): Geomorphological evidences of retreat of the Gangotri glacier and its characteristics. Current Science, Vol. 80, pp. 87-94.

13. Negi, H., Snehmani, S., Thakur, N.K. (2008): Operational Snow cover monitoring in NW-Himalaya using Terra and Aqua MODIS imageries, Proceedings. International workshop on snow, Ice, Glacier and Avalanches, IIT Mumbai, India, pp. 11-25.

14. Raina, V. and Srivastava, D. (2008): Glacier Atlas of India. Geological Society of India, Banglore.

15. Raj, K.B.G. (2011): Recession and reconstruction of Milam glacier, Kumaun Himalaya, observed with satellite imagery. Current Science, Vol. 100 (9), pp. 1420-1425.

16. Raj, K.B.G., Kumar, K.V., Mishra, R., Mukhtar, M.A. (2014): Remote Sensing based assessment of glacial lake growth on Milam glacier, Goriganga basin, Kumaun Himalaya. Journal of Geological Society of India, Vol. 83 (4), pp. 385-392.

17. Rashid, I., Romshoo, S.A., Abdullah, T. (2017): The recent deglaciation of Kolahoi valley in Kashmir Himalaya, India in response to the changing climate. Journal of Asian Earth Science, Vol. 138, pp. 38-50. 